\title{
PALM2 wt Allele
}

National Cancer Institute

\section{Source}

National Cancer Institute. PALM2 wt Allele. NCI Thesaurus. Code C158482.

Human PALM2 wild-type allele is located in the vicinity of 9q31.3 and is approximately 311 $\mathrm{kb}$ in length. This allele, which encodes paralemmin-2 protein, may play a role in cell shape. 